ISSN: 2469-4142

\title{
Journal of Nutritional Biology
}

\section{Research Article}

\section{Assessment of a Correlation between Malnutrition, Serum Hypotransferrin and Chronic Skin Ulcers}

\author{
Crisci $\mathrm{A}^{1^{*}}$, Crisci $\mathrm{M}^{2}$ and Pollastro $\mathrm{L}^{3}$
}

\author{
'Unit of Dermosurgery, Cutaneous Transplantations and Hard-to-Heal Wound "Villa Fiorita" Private Hospital, \\ Aversa, Caserta, Italy \\ ${ }^{2}$ Faculty of Medicine and Surgery - Vasile Goldis Western University of Arad, Romania \\ ${ }^{3}$ Department of Mathematics (Federico Enriques), Faculty of Mathematical, Physical an Natural Sciences, \\ University of Milan, Italy
}

Received: Oct 04, 2016; Accepted: Nov 14, 2016; Published: Nov 18, 2016

\section{Abstract}

Aim. The aims of this study were to evaluate the correlation between malnutrition, serum hypotransferrin and chronic skin ulcers and the effect of supplementation with a dietary integrator on wound healing. The study population was 20 patients with chronic skin ulcers (12 men and 8 women; mean age $75.58 \pm 8.51$ years). Monthly assessments were carried out for 6 months (V1-V6) and comprised measurement of changes in wound surface area and blood chemistry parameters (hemoglobin [Hb], total proteins, albumin, transferrin, iron, total iron-binding capacity [TIBC], latent iron-binding capacity [LIBC], transferrin saturation index). Nutritional supplementation with an oral dietary integrator was initiated at day 45 . At day 45 , the mean blood chemistry values were: serum albumin $2.73 \pm 1.07 \mathrm{~g} / \mathrm{dL}(45.05 \pm 15.84 \%)$; total proteins $6.35 \pm 0.65 \mathrm{~g} / \mathrm{dL}$; total lymphocyte count $24.17 \pm 0.09 \%$; serum $\mathrm{Hb} 10.86 \pm 1.47 \mathrm{~g} / \mathrm{dL}$; serum trasferrin $165.92 \pm 75.95 \mathrm{~g} / \mathrm{dL}$; serum iron $40.5 \pm 19.65 \mathrm{mg} \%$; TIBC $207.4 \pm 94.94$ mgr\%; LIBC $166.9 \pm 92.45 \mathrm{mg} \%$; transferrin saturation index $20.63 \pm 9.73 \%$. These values indicated moderate protein malnutrition. The mean wound surface area was $56.92 \pm 47.95 \mathrm{~cm}^{2}$. At 90 days (V4) the mean values were: serum albumin $3.43 \pm 0.68 \mathrm{~g} / \mathrm{dL}(48.05 \pm 8.15 \%)$; serum proteins $6.91 \pm 0.51 \mathrm{~g} / \mathrm{dL}$; total lymphocyte count 40.44 $\pm 0.44 \%$; serum Hb $12.47 \pm 1.91 \mathrm{~g} / \mathrm{dL}$; serum trasferrin $223.73 \pm 104.07 \mathrm{~g} / \mathrm{dL}$; serum iron $51.09 \pm 22.66 \mathrm{mgr} \%$; TIBC $279.66 \pm 130.09$ mgr\%; LIBC $228.57 \pm 133.37 \mathrm{mgr} \%$; transferrin saturation index $21.54 \pm 12.15 \%$. The mean wound surface area was $20.41 \pm 25.91 \mathrm{~cm}^{2}$. In conclusion, a correlation emerged between hypotransferrinemia and chronic skin ulcers, as demonstrated by the improvement in both parameters with treatment. Supplementation with the oral dietary integrator led to an increase in serum transferrin, and particularly in serum $\mathrm{Hb}$ and proteins and total lymphocyte counts, stimulating the healing of the chronic skin ulcers.

Keywords: Skin ulcer; Malnutrition; Dietary supplements; Hypotransferrin

*Correspondence: Crisci A, "Villa Fiorita” Private Hospital, Aversa, Caserta, Italy, Tel:+0393388722799;

Fax:+0390823714196; E-mail: alessandrocrisci@libero.it 


\section{Introduction}

Various risk factors interact to produce the tissue damage seen in patients with chronic skin ulcers. Among the extrinsic and intrinsic causes are uninterrupted pressures on a particular body area, immobility, incontinence, and advanced age. Although the physiological consequences of immobility are regarded as the main predisposing factor, just as important is the direct causal relationship between nutritional status and the development of pressure ulcers. Biochemical indicators of malnutrition include levels of serum albumin and transferrin and total lymphocyte count. Numerous studies have shown an association between hypoalbuminemia and pressure ulcers (Table 1) [1,2]. The aim of this study was to determine whether there is an association between hypotransferrinemia and chronic skin ulcers or both have been an independent factors.

$\mathrm{NP}^{\circledR}$, the study product, is a dietary integrator composed of vitamins, amino acids, zinc and echinacea. It is indicated in asthenia and loss of appetite to stimulate immune system defenses. It is supplied in single-dose vials containing vitamin $\mathrm{B} 1(0.82 \mathrm{mg})$, vitamin $\mathrm{B} 2$ (1.05 $\mathrm{mg}$ ), vitamin B6 (1.05 mg), vitamin PP (also called vitamin B3 or niacin) (12 mg), vitamin B12 (1.87 mg), folic acid (150 mg), pantothenic acid (vitamin B5) (4.5 $\mathrm{mg})$, vitamin C (60 mg), zinc (7.5 mg), L-arginine (150 $\mathrm{mg})$, royal jelly $(100 \mathrm{mg})$ and eucalyptus honey $(2 \mathrm{~g})$.

Arginine regulates many metabolic and physiologic functions, several of which aid in promoting wound healing and tissue repair [3,4]. Experimental studies have shown that L-arginine supplementation enhances tissue repair markers, increases protein and hydroxyproline content in wounds, and improves $T$ lymphocyte function [3,4]. In addition, activated macrophages release arginine-derived nitric oxide, which exerts a bactericidal and a vasodilatory action on the vessels surrounding the wound, promoting the tissue oxygenation needed for wound repair $[3,4]$.

Vitamin C is essential for connective tissue synthesis and collagen metabolism. Together with proteins, zinc plays an important role in collagen tissue synthesis. Nearly $80 \%$ of patients with pressure ulcers are noted to have zinc deficiency and zinc levels are thought to parallel albumin, a known zinc carrier [5-7]. Transferrin, a rapid turnover protein, by virtue of its short half life, is used as a marker of nutritional status. While this affords a distinct advantage over other biomarkers, transferrin levels tend to increase in martial deficiency. Levels between 100 and $150 \mathrm{mg} / \mathrm{mL}$ indicate moderate protein depletion and levels $<100 \mathrm{mg} / \mathrm{mL}$ indicate severe protein depletion.

Nutritional status is a recognized risk factor for pressure ulcers, which will inevitably develop when comorbidities and sustained pressure on body areas are present. As defined by anthropometric and biochemical parameters, poor nutritional status or malnutrition is common in patients with chronic ulcers: $70 \%$ of those with pressure ulcers and $55 \%$ of those at risk for developing pressure ulcers are undernourished. Malnutrition is not the result of protein loss from the wounds but rather is the manifestation of a primary decrease in protein intake due to malnutrition. In patients with pressure ulcers a significant association has been shown between hypoalbuminemia $(<3 \mathrm{~g} / \mathrm{dL})$, total lymphocyte count $\left(<1000 / \mathrm{mm}^{3}\right)$, total proteins $(<6 \mathrm{~g} / \mathrm{dL})$, diastolic blood pressure $(<50 \mathrm{mmHg})$ and mortality.

\section{Materials and Methods}

\section{Primary aim}

The primary aim was to determine whether there was a correlation between hypotransferrinemia, chronic skin ulcers and malnutrition or both have been an independent factors. Data were obtained by measuring blood chemistry values (serum transferrin, serum albumin, total lymphocyte count [TLC], hemoglobin $[\mathrm{Hb}]$, total iron-binding capacity [TIBC], latent ironbinding capacity [LIBC], transferrin saturation index) with immunoturbidimetric assay on serum, reepithelialization rate, and changes in wound surface area as measured using the Calcderm ${ }^{\circledR}$ software program (software developed by our working group) [810].

This study was approved by ethics committees 
(ethical approval) of the Western University of Arad, Romania and "Villa Fiorita" Private Hospital, Aversa, Caserta, Italy.

\section{Secondary aim}

The secondary aim was to evaluate the usefulness of the study product $\left(\mathrm{NP}^{\circledR}\right)$ in the treatment of chronic skin ulcers by comparing the changes in blood chemistry parameters and wound surface area after 3-months therapy with the oral dietary integrator.

This was a single-center, open-label study. The study was divided into three phases:

baseline screening (1 week [V1]);

monthly assessment (V2, V3);

monthly assessment (V4, V5, V6).

At day 45 (beginning of the follow-up period, V2-V3), treatment with the study product was initiated. The patients were instructed to take the dietary integrator 3 times daily with their main meals for 3 months.

The study population was 20 patients ( 12 men and 8 women; mean age, 75.58 years \pm SD [Standard Deviation] 8.51). The wound diagnosis was trophic ulcer over the sacrum $(\mathrm{N} .=8)$, Martorell hypertensive ischemic leg ulcer of the left leg $(\mathrm{N} .=2)$, diabetic foot ulcer of the right foot $(\mathrm{N} .=2)$, decubitus heel ulcer $(\mathrm{N} .=4)$, and postsurgical ulcer $(\mathrm{N} .=4)$. Patients were consecutively screened and enrolled in the study.

Inclusion criteria were: written informed consent: age $\geq 18$ years; either sex; bed-ridden patients with one or more chronic skin ulcers; malnutrition as measured by blood chemistry $(\mathrm{Hb}<12 \mathrm{~g} / \mathrm{dL}$, serum albumin $<3.5$ $\mathrm{g} / \mathrm{dL}$; serum transferrin $<170 \mathrm{~g} / \mathrm{dL}$ ) and the Instant Nutritional Assessment screening tool. Exclusion criteria were: age < 18 years; self-sufficiency; use of a dietary integrator in the 12 months prior to enrollment in the study. Patients could withdraw from participation in the study at any time because of: premature death; informed and free decision; occurrence of an exclusion criterion; occurrence of adverse events that require discontinuation of the treatment under study at the investigator's discretion.

\section{Statistical analysis}

Inferential data analysis was used to compare the data obtained before (before day 45) and during treatment (after day 45) using biomedical statistics as described by Sofastats (ver. 1.4.6. 2012). Patient demographics are expressed as the means, standard deviation (SD), median, range, and correlation coefficient. Statistical significance of the data obtained between V1 and V4 was tested using ANOVA, Student's $t$-test, and the $t$-test for independent samples calculated with a confidence interval of $95 \%[11,12]$.

\section{Results}

All 20 patients completed the study (Table 2). The mean blood chemistry values at the beginning of followup (V1) were: serum albumin $2.73 \pm 1.07 \mathrm{~g} / \mathrm{dL}$ (45.05 \pm $15.84 \%)$; serum proteins $6.35 \pm 0.65 \mathrm{~g} / \mathrm{dL}$; TLC $24.17 \pm$ $0.09 \% ; \mathrm{Hb} 10.86 \pm 1.47 \mathrm{~g} / \mathrm{dL}$; serum transferrin 165.92 $\pm 75.95 \mathrm{~g} / \mathrm{dL}$; serum iron $40.5 \pm 19.65 \mathrm{mg} \%$; TIBC 207.4 $\pm 94.94 \mathrm{mg} \%$; LIBC $166.9 \pm 92.45 \mathrm{mg} \%$; transferrin saturation index $20.63 \pm 9.73 \%$. These values indicated moderate protein malnutrition (Table 1). The mean wound surface area was $56.92 \pm 47.95 \mathrm{~cm}^{2}$.

At day 30 (V2) the mean blood chemistry values were: serum albumin $3.13 \pm 0.75 \mathrm{~g} / \mathrm{dL}(43.46 \pm 15.29 \%)$; serum proteins $6.17 \pm 0.63 \mathrm{~g} / \mathrm{dL} ;$ TLC $25.23 \pm 15.28 \%$; $\mathrm{Hb} 10.77 \pm 2.07 \mathrm{~g} / \mathrm{dL}$; serum transferrin $191.82 \pm 90.67$ $\mathrm{g} / \mathrm{dL}$; serum iron $42.64 \pm 20.44 \mathrm{mg} \%$; TIBC $239.77 \pm$ $113.34 \mathrm{mg} \%$; LIBC $197.9 \pm 114.80 \mathrm{mg} \%$; transferrin saturation index $20.22 \pm 11.04 \%$. The mean wound surface area was $50.27 \pm 48.47 \mathrm{~cm}^{2}$.

At day 60 (V3, 15 days since the start of treatment) the mean blood chemistry values were: serum albumin $3.29 \pm 0.81 \mathrm{~g} / \mathrm{dL}(47.976 \pm 8.01 \%)$; serum proteins 6.71 $\pm 0.67 \mathrm{~g} / \mathrm{dL}$; TLC $29.41 \pm 12.53 \% ;$ Hb $11.64 \pm 1.92 \mathrm{~g} /$ $\mathrm{dL}$, serum transferrin $208.80 \pm 92.04 \mathrm{~g} / \mathrm{dL}$; serum iron $73.82 \pm 48.45 \mathrm{mg} \%$; TIBC $270.22 \pm 113.15 \mathrm{mg} \%$; LIBC $207.36 \pm 124.94 \mathrm{mg} \%$; transferrin saturation index $26.90 \pm 21.68 \%$. The mean wound surface area was $45.27 \pm 46.25 \mathrm{~cm}^{2}$.

At day 90 (V4 to 45 days from start of treatment) the 
mean blood chemistry values were: serum albumin $3.43 \pm 0.68 \mathrm{~g} / \mathrm{dL}(48.05 \pm 8.15 \%)$; serum proteins 6.91 $\pm 0.51 \mathrm{~g} / \mathrm{dL}$; TLC $40.44 \pm 0.44 \% ; \mathrm{Hb} 12.47 \pm 1.91 \mathrm{~g} /$ $\mathrm{dL}$; serum transferrin $223.73 \pm 104.07 \mathrm{~g} / \mathrm{dL}$; serum iron $51.09 \pm 22.66 \mathrm{mg} \%$; TIBC $279.66 \pm 130.09 \mathrm{mg} \%$; LIBC $228.57 \pm 133.37 \mathrm{mg} \%$; transferrin saturation index $21.54 \pm 12.15 \%$. The mean wound surface area was $20.41 \pm 25.91 \mathrm{~cm}^{2}$.

At day 120 (V5) the mean blood chemistry values were: serum albumin $3.42 \pm 0.16 \mathrm{~g} / \mathrm{dL}(49.66 \pm 3.71 \%)$; serum proteins $6.30 \pm 0.75 \mathrm{~g} / \mathrm{dL}$; TLC $28.38 \pm 10.54 \%$; $\mathrm{Hb} 11.96 \pm 1.18 \mathrm{~g} / \mathrm{dL}$; serum transferrin $203.6 \pm 109.61$ $\mathrm{g} / \mathrm{dL}$; serum iron $48.60 \pm 18.76 \mathrm{mg} \%$; TIBC $254.50 \pm$ $137.02 \mathrm{mg} \%$; LIBC $205.90 \pm 137.11 \mathrm{mg} \%$; transferrin saturation index $21.95 \pm 11.55 \%$. These values indicated the absence of protein malnutrition. The mean wound surface area was $19.9 \pm 23.05 \mathrm{~cm}^{2}$.

At day 150 (V6) the mean blood chemistry values were: serum albumin $3.18 \pm 0.16 \mathrm{~g} / \mathrm{dL}(51.4 \pm 3.71 \%)$; serum proteins $6.18 \pm 0.75 \mathrm{~g} / \mathrm{dL}$; TLC $30.0 \pm 10.54 \%$; $\mathrm{Hb} 12.8 \pm 1.18 \mathrm{~g} / \mathrm{dL}$; serum transferrin $160.0 \pm 109.61 \mathrm{~g} /$ dL; serum iron $30.0 \pm 18.76 \mathrm{mg} \%$; TIBC $200.0 \pm 137.02$ $\mathrm{mg} \%$; LIBC $170.0 \pm 50.97 \mathrm{mg} \%$; transferrin saturation index $15.0 \pm 11.55 \%$. The mean wound surface area was $17.2 \pm 23.0547 \mathrm{~cm}^{2}$.

\section{Discussion}

Our data show an improvement in all parameters, with a marked increase in mean serum transferrin from $165.92 \mathrm{~g} / \mathrm{dL}$ to $203.6 \mathrm{~g} / \mathrm{dL}$ between V1 and V5, indicating a change in nutritional status from mild to no malnutrition, an improvement of $18.5 \%$, and a concomitant reduction of $69.8 \%$ in mean wound surface area from 56.92 to $17.2 \mathrm{~cm}^{2}$ between $\mathrm{V} 1$ and V6. Comparison of the data from two study periods (day 0-45 from the start of the tral and day 46-150) shows that the mean wound surface area decreased by $26 \%$ in the
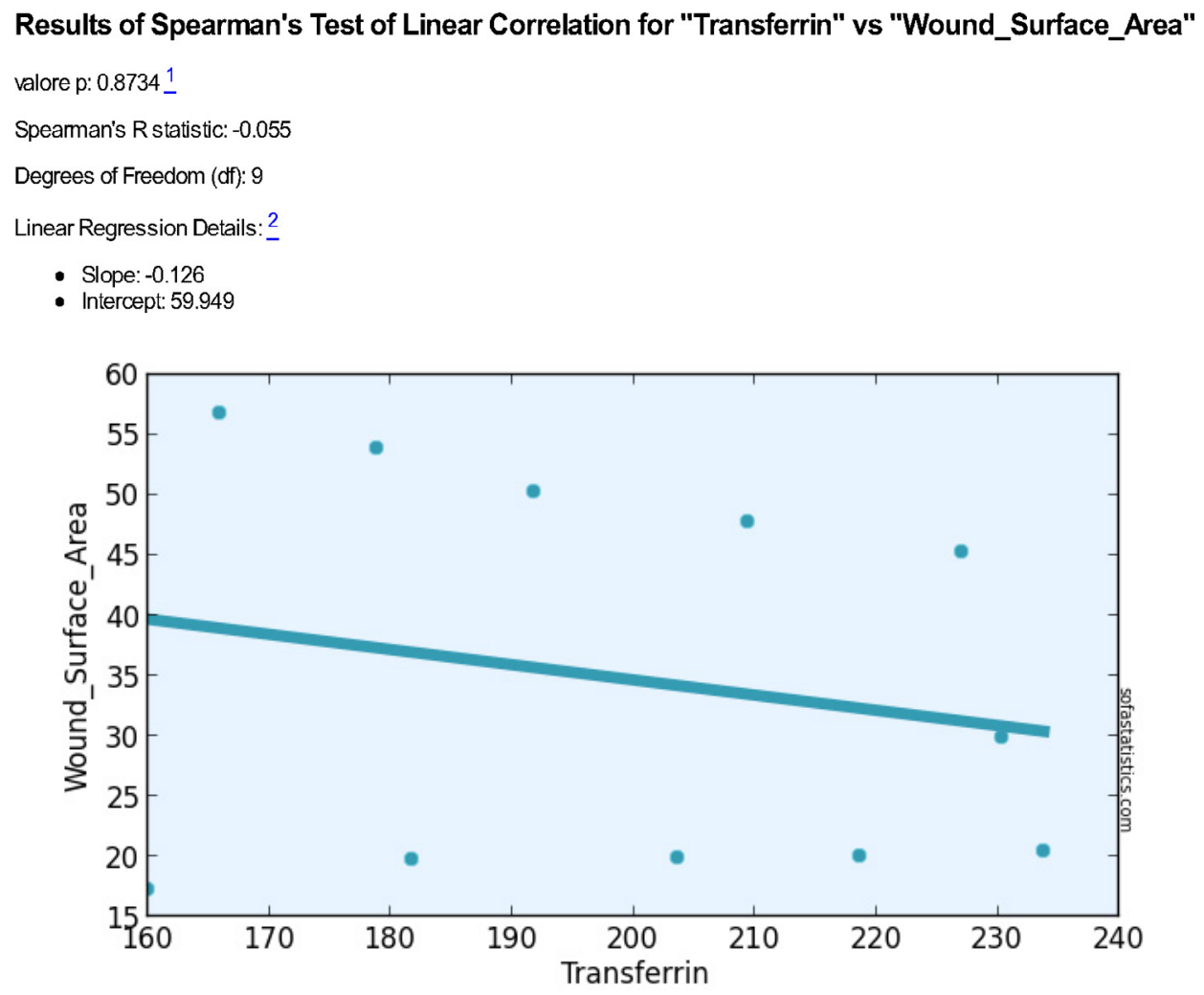

- "Transferrin" vs "Wound_Surface_Area"

Figure 1: Correlation coefficient for changes in wound surface area and serum transferrin levels. 
Results of Spearman's Test of Linear Correlation for "Hb" vs "Wound_Surface_Area"

valore $\mathrm{p}:<0.001(4.546 \mathrm{e}-4)_{-}^{1}$

Spearman's R statistic: -0.873

Degrees of Freedom (df): 9

Linear Regression Details: $\underset{-}{2}$

- Slope: -20.522

- Intercept: 275.93

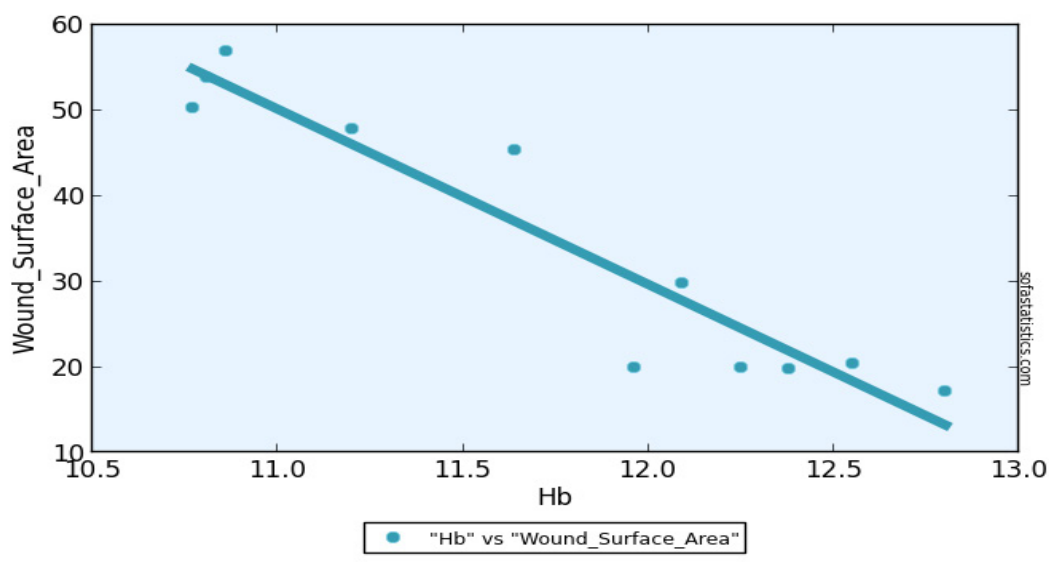

Figure 2: Correlation coefficient for changes in wound surface area and serum hemoglobin levels.

Results of Spearman's Test of Linear Correlation for "Albumin" vs "Wound_Surface_Area"

valore p: 0.028861

Spearman's R statistic: - 0.655

Degrees of Freedom (df): 9

Linear Regression Details: $\underline{2}$

- Slope: -60.674

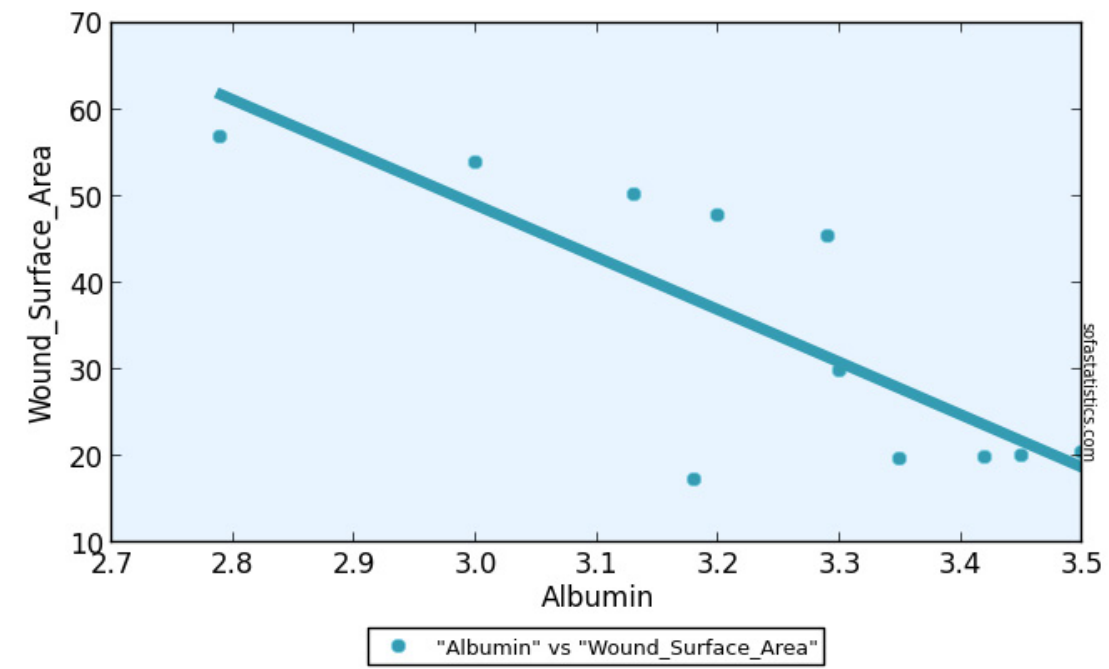

Figure 3: Correlation coefficient for changes in wound surface area and serum albumin levels. 
Results of Spearman's Test of Linear Correlation for "Hb" vs "Transferrin"

valore p: 0.57391

Spearman's R statistic: 0.191

Degrees of Freedom (df): 9

Linear Regression Details: 2

- Slope: 8.002

- Intercept: 106.039

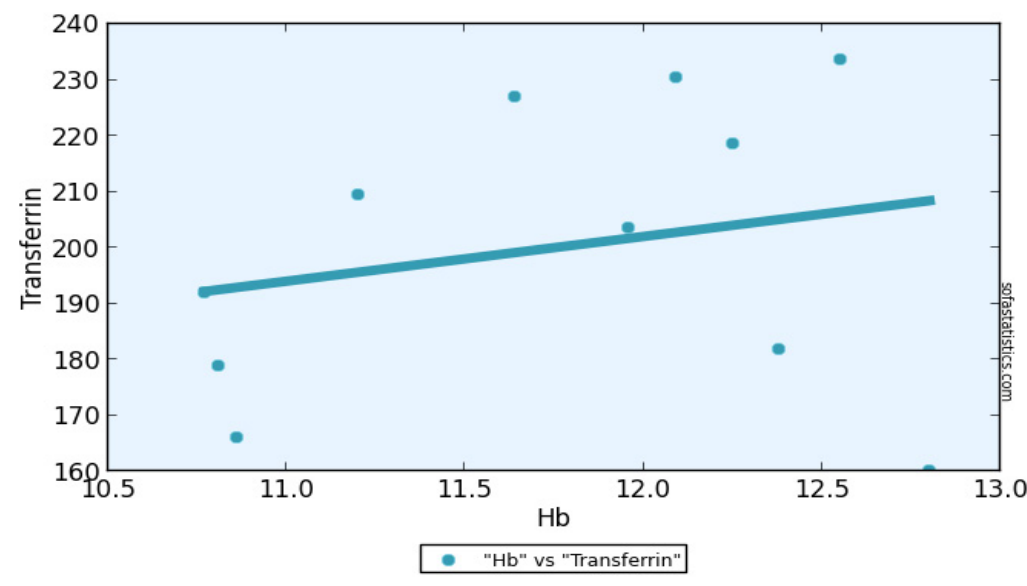

Figure 4: Correlation coefficient for changes in $\mathrm{Hb}$ and serum transferrin levels.

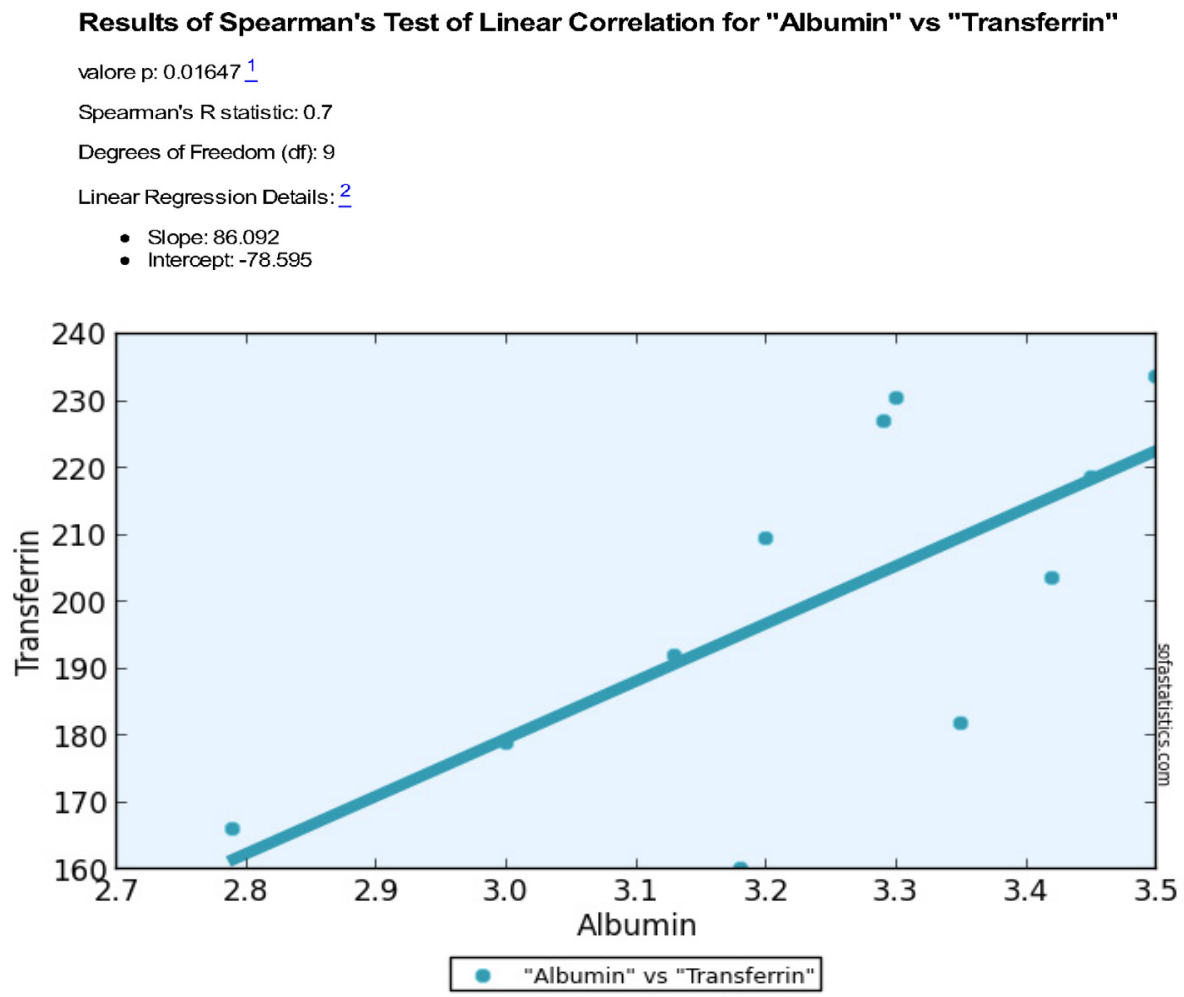

Figure 5: Correlation coefficient for changes in Albumin and serum transferrin levels. 


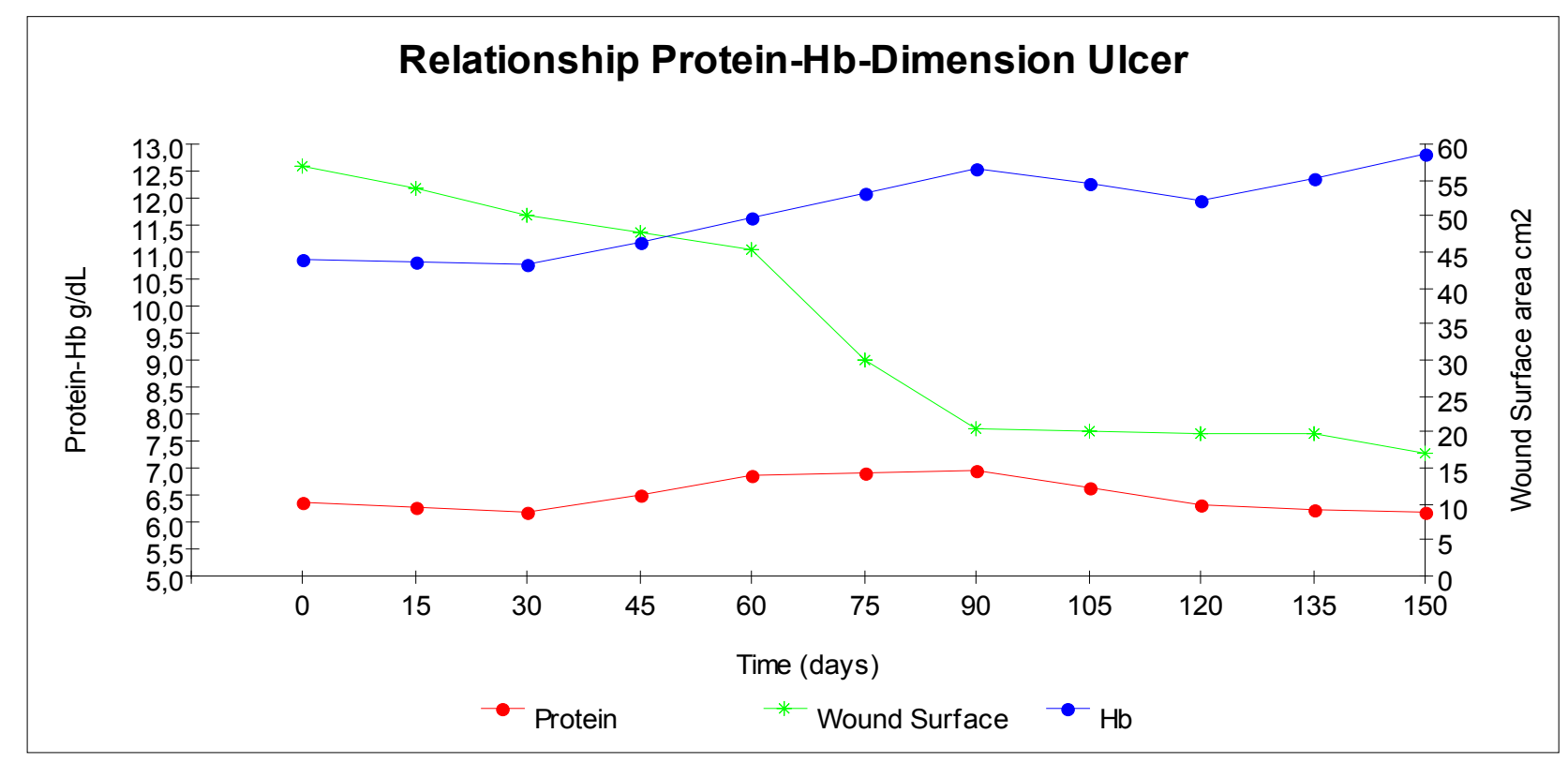

Figure 6: Time relationship between changes in wound surface area, serum protein and haemoglobin levels. Proteins- $\mathrm{Hb}(\mathrm{g} / \mathrm{dL})$; Wound surface area $\left(\mathrm{cm}^{2}\right)$; time (days); proteins, surface area, haemoglobin.

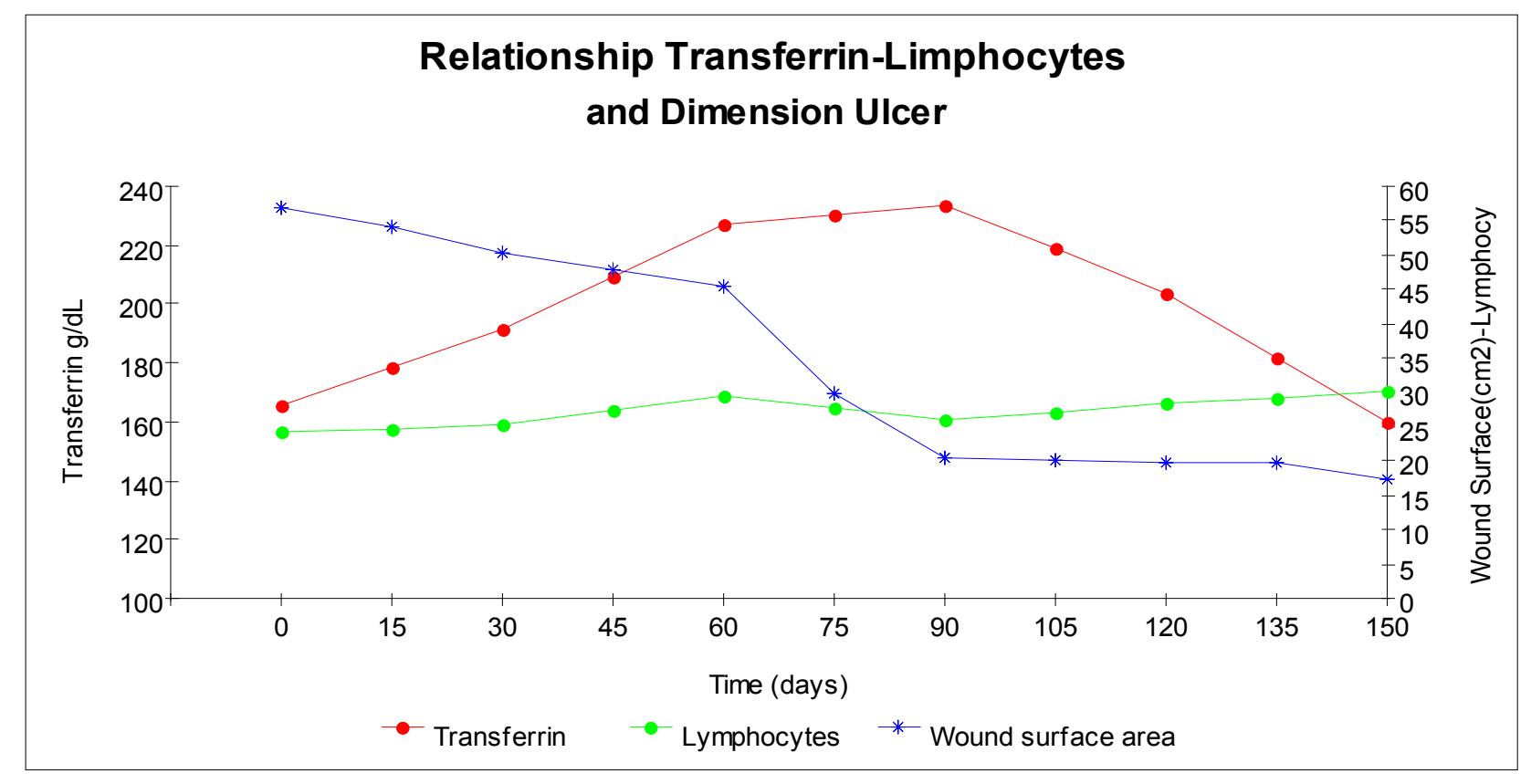

Figure 7: Time relationship between changes in wound surface area, serum transferrin and total lymphocytes count. Transferrin ( $\mathrm{g} / \mathrm{dL})$; Wound surface area $\left(\mathrm{cm}^{2}\right)$; lymphocytes count (\%); time (days); transferrin, lymphocytes count, surface area. 

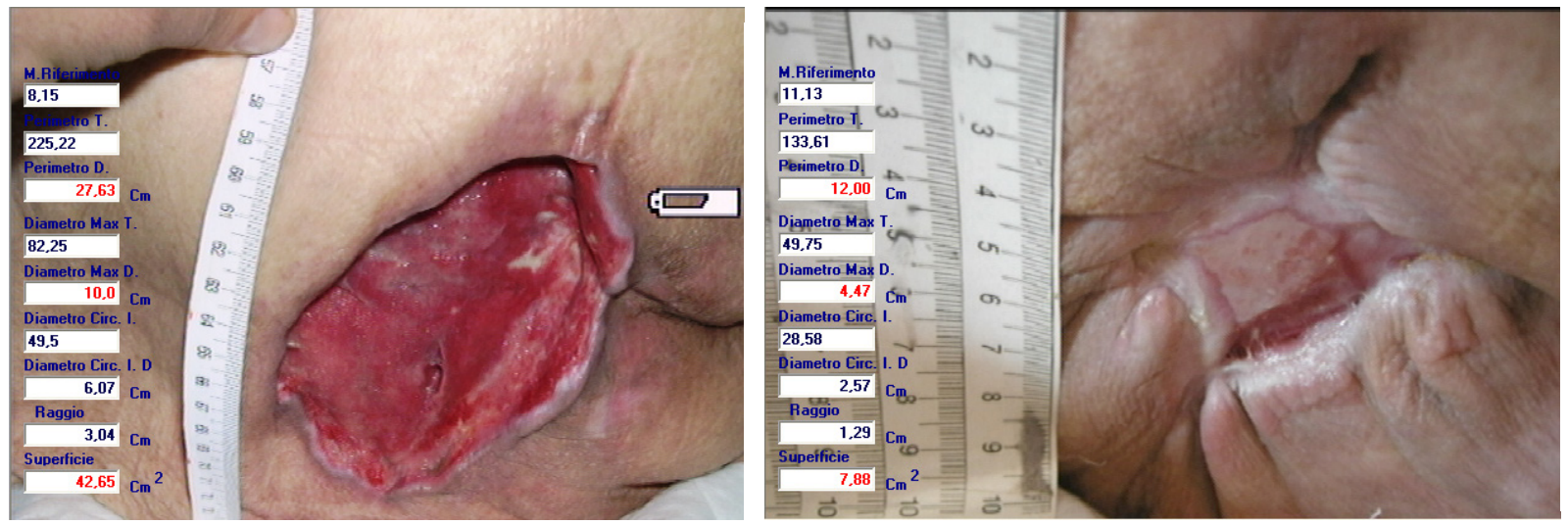

Figure 8: Before and After 120 days after administration of the integrator (measurements taken with Calcderm ${ }^{\circledR}$ software).
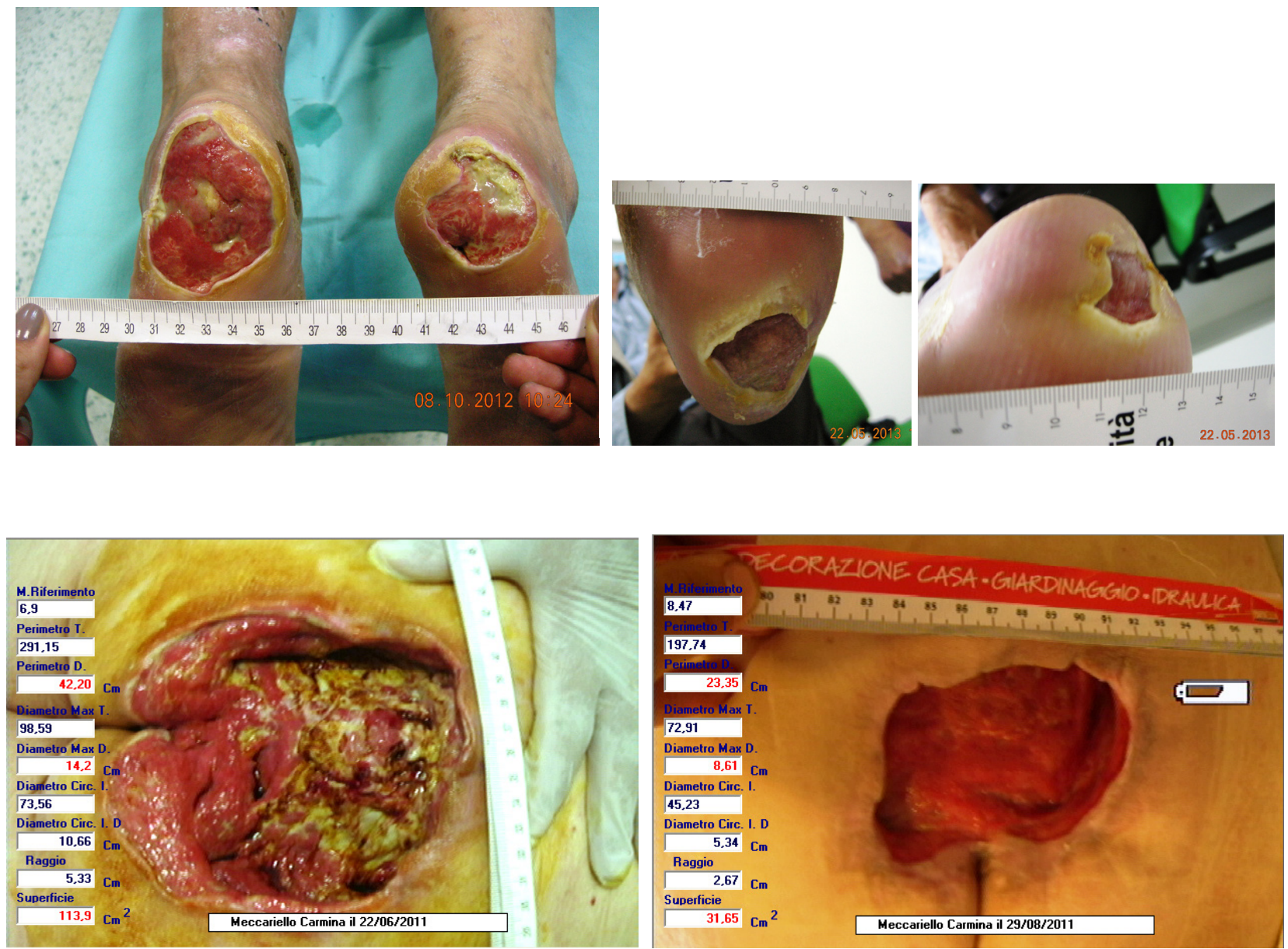

Figure 9: Before and After 60 days after administration of the integrator (measurements taken with Calcderm ${ }^{\circledR S o f t w a r e)}$. 
Table 1: Malnutrition Indicators [1,2]

\begin{tabular}{|c|c|c|c|c|}
\hline \multicolumn{5}{|c|}{ Malnutrition } \\
\hline & Reference values & Mild & Moderate & Severe \\
\hline Albumin (g/dl) & $>3.5$ & $3.0-3.5$ & $2.5-3$ & $<2.5$ \\
\hline Transferrin $(\mathrm{mg} / \mathrm{dl})$ & $>200$ & $180-200$ & $160-180$ & $<160$ \\
\hline Retinol Binding Protein $(\mathrm{mg} / \mathrm{ml})$ & $>250$ & $<250$ & & \\
\hline Thyroxin Binding Prealbumin $(\mathrm{mg} / \mathrm{ml})$ & $>50$ & $<250$ & & \\
\hline Total lymphocyte count $\left(\mathrm{n} / \mathrm{mm}^{3}\right)$ & $>1800$ & $1500-1800$ & $900-1500$ & $<900$ \\
\hline Creatininuria/Height $(\mathrm{mg} / \mathrm{cm} / \mathrm{die})$ & & & & \\
\hline In men & $>8.5$ & $7.6-6.8$ & $6.8-6.0$ & $<6.0$ \\
\hline In women & $>5.8$ & $5.2-4.5$ & $4.6-4.0$ & $<4.0$ \\
\hline
\end{tabular}

Table 2: Dose-time-effect relationship.

\begin{tabular}{|c|c|c|c|c|c|c|c|c|c|c|c|}
\hline $\begin{array}{c}\text { Time } \\
\text { (days) }\end{array}$ & \multicolumn{2}{|c|}{$\begin{array}{c}\text { Albumin } \\
\mathbf{g} / \mathbf{d l} \%\end{array}$} & $\begin{array}{c}\text { Protein } \\
\mathbf{g} / \mathbf{d l}\end{array}$ & $\begin{array}{c}\text { Lymphocytes } \\
\%\end{array}$ & $\begin{array}{c}\text { Hb } \\
\mathbf{g} / \mathbf{d L}\end{array}$ & $\begin{array}{c}\text { Transferrin } \\
\mathbf{g} / \mathbf{d L}\end{array}$ & $\begin{array}{c}\text { Iron } \\
\mathbf{m g} \%\end{array}$ & $\begin{array}{c}\text { T.I.B.C } \\
\mathbf{m g} \%\end{array}$ & $\begin{array}{c}\text { L.I.B.C } \\
\mathbf{m g} \%\end{array}$ & $\begin{array}{c}\text { I.S.T. } \\
\%\end{array}$ & $\begin{array}{c}\text { Wound } \\
\text { Surface } \\
\mathbf{C m}^{2}\end{array}$ \\
\hline 0V1 & 2.73 & 45.05 & 6.35 & 24.17 & 10.86 & 165.92 & 40.50 & 207.4 & 166.9 & 20.63 & 56.92 \\
\hline 30V2 & 3.13 & 43.46 & 6.17 & 25.23 & 10.77 & 191.82 & 42.64 & 239.8 & 197.1 & 20.22 & 50.27 \\
\hline 60V3 & 3.29 & 50.41 & 6.85 & 29.41 & 11.64 & 227.00 & 83.11 & 292.2 & 222.8 & 28.59 & 45.36 \\
\hline 90V4 & 3.43 & 48.05 & 6.91 & 40.44 & 12.47 & 279.66 & 51.09 & 292.2 & 228.6 & 21.54 & 20.41 \\
\hline 120V5 & 3.42 & 49.66 & 6.30 & 28.38 & 11.96 & 203.60 & 48.60 & 254.5 & 125.3 & 21.95 & 20.10 \\
\hline 150V6 & 3.18 & 51.40 & 6.18 & 30.00 & 12.80 & 160.00 & 30.00 & 200.0 & 170.0 & 15.00 & 17.20 \\
\hline Student & $\mathrm{p}>0.05$ & $\mathrm{p}>0.05$ & $\mathrm{p}<0.05$ & $\mathrm{p}>0.05$ & $\mathrm{p}<0.05$ & $\mathrm{p}>0.05$ & $\mathrm{p}>0.05$ & $\mathrm{p}>0.05$ & $\mathrm{p}>0.05$ & $\mathrm{p}>0.05$ & $\mathrm{p}<0.05$ \\
\hline
\end{tabular}

first period and by $59 \%$ in the second. The correlation coefficient between wound surface area and transferrin levels indicates a weakly positive correlation $(r=-0.055$; $\mathrm{t}=-0.792 ; \mathrm{P}=0.8734$ ) (Figure 1), a strong positive correlation between the changes in wound surface area and $\mathrm{Hb}$ levels $(r=0.873 ; t=-5.09 ; P=0.001)$ (Figure 2) and between wound surface area and levels serum albumin ( $r=-0.655 ; t=-2.311 ; P=0.02886)$ (Figure 3$)$, a weakly positive correlation between $\mathrm{Hb}$ and transferrin levels ( $r=-0.191 ; t=0.337 ; P=0.5739$ ) (Figure 4), and a strong correlation between albumin and transferrin levels ( $r=0.754 ; t=2.298 ; P=0.01647$ ) (Figure 5). The daily re-epithelialization rate calculated according to the equation.

[(EstT0 $\mathrm{cm}^{2}-$ EstTX $\left.\mathrm{cm}^{2}\right) /$ EstT0 $\left.\mathrm{cm}^{2}\right] / X$ between V3 and V4 was 0.019 or $>50 \%$.

Significant differences in changes in blood chemistry parameters measured between $\mathrm{V} 1$ and $\mathrm{V} 4$ were recorded for proteins, TLC, $\mathrm{Hb}$ and wound surface area (Table 3). 
Table 3: Tests of significance of difference.

\begin{tabular}{|c|c|c|c|c|c|c|}
\hline Parameter & \multicolumn{2}{|c|}{ Variance } & t-Student & \multicolumn{2}{|c|}{$\begin{array}{l}\text { t-test for independent } \\
\text { samples }\end{array}$} & $\begin{array}{l}\text { Significance of } \\
\text { Difference }\end{array}$ \\
\hline Albumin gr/dl & $\mathrm{F}=3.35$ & $P=0.082$ & $p>0.05$ & $\mathrm{t}=-1.831$ & I.C. $95 \%-1.50-0.10$ & NS \\
\hline Albumin \% & $\mathrm{F}=0.31$ & $P=0.583$ & $p>0.05$ & $t=-0.559$ & I.C.95\% $-14.20-8.20$ & NS \\
\hline Proteins gr/dl & $F=5.05$ & $P=0.036$ & $p<0.05$ & $t=-2.248$ & I.C. $95 \%-1.08--0.04$ & Significant \\
\hline $\begin{array}{l}\text { Transferrin } \\
\text { gr/dl }\end{array}$ & $\mathrm{F}=2.21$ & $P=0.152$ & $p>0.05$ & $\mathrm{t}=-1.488$ & I.C. $95 \%-138.84-23.22$ & NS \\
\hline $\begin{array}{l}\text { Lymphocytes } \\
\%\end{array}$ & $F=14301.78$ & $P=0.000$ & $p<0.05$ & $t=-119.59$ & I.C. $95 \%-16.55--15.99$ & Significant \\
\hline $\mathrm{Hb}$ gr/dl & $\mathrm{F}=4.91$ & $P=0.038$ & $p<0.05$ & $t=-2.215$ & I.C. $95 \%-3.13--0.09$ & Significant \\
\hline Iron mgr\% & $\mathrm{F}=1.37$ & $P=0.255$ & $p>0.05$ & $t=-1.171$ & I.C.95\% -29.45 - 8.27 & NS \\
\hline $\begin{array}{c}\text { Wound } \\
\text { surface area } \\
\mathrm{cm}^{2}\end{array}$ & $\mathrm{~F}=4.94$ & $P=0.038$ & $p<0.05$ & $\mathrm{t}=2.222$ & I.C. $95 \% 2.23-70.79$ & Significant \\
\hline T.I.B.C.mgr\% & $\mathrm{F}=2.21$ & $P=0.152$ & $p>0.05$ & $t=-1.488$ & I.C. $95 \%-173.55-29.03$ & NS \\
\hline L.I.B.C.mgr\% & $\mathrm{F}=1.59$ & $P=0.222$ & $p>0.05$ & $t=-1.260$ & I.C. $95 \%-163.73-40.39$ & NS \\
\hline TSI \% & $\mathrm{F}=0.04$ & $P=0.848$ & $p>0.05$ & $t=-0.194$ & I.C. $95 \%-10.7-8.88$ & NS \\
\hline
\end{tabular}

\section{Conclusions}

Our data show a correlation between hypotransferrinemia and wound surface area, demonstrating a parallel improvement in both parameters during treatment with the study product. Our data also show a marked improvement in serum transferrin and a more pronounced improvement in serum $\mathrm{Hb}$, proteins and TLC (Figures 6 and 7), indicating that the oral dietary integrator aided in stimulating healing of the chronic skin ulcers (Figures 8 and 9). Chronic skin ulcers arise in a setting of the hypercatabolic syndrome with protein-energy malnutrition, leading to socalled metabolic death with the loss of $70 \%$ of protein reserves. Indeed, proteinenergy malnutrition is a recognized factor in delayed tissue repair.

Our results suggest that supplementation with this oral dietary integrator, starting at the early stages of pressure ulcer in bedridden patients with malnutrition symptoms, for 3 months 3 times daily can help heal skin wounds or at least reduce wound surface area.
The future studies can be conducted to see if the same results can be obtained by reducing the dose to two times a day, thus avoiding the occurrence of sporadic diarrhea, the only side effect recorded in the present study.

\section{Conflict of Interests}

The authors declare no competing interests related to this work.

\section{References}

1. Anhtony D, Reynolds T, Russell L (2000) An investigation into use of serum albumin in pressure sore prediction. J Adv Nurs 32: 359-365.

2. Shakersain B, Santoni G, Faxén-Irving G, Rizzuto $D$, Fratiglioni L, et al. (2016) Nutritional status and survival among old adults: an 11-year populationbased longitudinal study. Eur J Clin Nutr 70: 320325. 
3. Benati G, Delvecchio S, Cilla D, Pedone V (2001) Impact on pressare ulcer healing of an arginine enriched solution in patients with severe cognitive impairment. Arch Gerontol Geriatr (Suppl 1) 33: 4347

4. Crowe T, Brockbank C (2009) Nutrition therapy in the prevention and treatment of pressure ulcers. Wound Practice Res 2: 90-99.

5. Breslow RA, Hallfrisch J, Guy DG, Crawley B, Goldberg AP (1993) The importance of dietary protein in healing pressure ulcers. J Am Geriatr Soc 41: 357-362.

6. Norris JR, Reynolds RE (1971) The effect of oral zinc sulphate therapy on decubitus ulcers. J Am Geriatr Soc 19: 793-797.

7. Taylor TV, Rimmer S, Day B, Butcher J, Dymock IW (1974) Ascorbic acid supplementation in the treatment of pressure ulcers. J Clin Epidemiol 2: 544-546.

8. Crisci A, Moccia G, Malinconico FA, Foroni F, Agresti $E$, et al. (2011) Preliminary results of an experimental study of a measurement technique of ulcerative skin lesions. Acta Vuln 9: 53-63.
9. Crisci A, Lerro G, Boccalone E, Crisci M (2014) Assessment of correlation between serum hypotransferrin and chronic skin ulcers. Acta Vuln 12: 13-22.

10. Crisci A, Crisci M , Boccalone E (2014) Final results of an experimental research about a technique of a measurement of skin lesions. Esp Derm 16: 147152.

11. Bulpitt CJ (1987) Confidence intervals. The Lancet 4:376-379.

12. Marubini E, Reina G. Statistics notes. Presentation of software for the measurement of absolute measures of effect and relative. Ital Heart $\mathrm{J}$ (suppl.2004) 5: 466-471.

Copyright: $\odot$ Crisci et al. This is an Open Access article distributed under the terms of the Creative Commons Attribution License, which permits unrestricted use, distribution, and reproduction in any medium, provided the original work is properly cited. 